\title{
ABSORPTION OF NEEM (Azadirachta indica) SEED OIL BY SPLIT- BAMBOO (Bambusa vulgaris) AT DIFFERENT TEMPERATURE REGIMES AND TREATMENT DURATIONS
}

\author{
Andrew Agbontalor Erakhrumen ${ }^{1}$ \\ ${ }^{1}$ Wood and Fibre Scientist, Dr., University of Ibadan, Ibadan, Nigeria - erakhrumen@ yahoo.com
}

Recebido para publicação: 28/01/2010 - Aceito para publicação: 21/12/2011

\begin{abstract}
This study was carried out to evaluate absorption of neem (Azadirachta indica A. Juss) seed oil by split-bamboo (Bambusa vulgaris Schrad. ex J.C. Wendl.) samples at two different treatment temperature (TT) regimes and durations of treatment (DOT). A multivariate linear regression model was also developed for predicting oil absorption (OA) from TT and DOT. Split-bamboo specimens from the same source with same dimension were oven-dried at $103 \pm 2{ }^{\circ} \mathrm{C}$, conditioned to $11.76 \%$ mean moisture content, and treated by completely soaking a set in oil at an ambient room temperature of $25 \pm 2{ }^{\circ} \mathrm{C}$ for 24 hours (A) and by soaking the other in hot oil at $60{ }^{\circ} \mathrm{C}$ for 4 hours (B). Results obtained showed that test specimens for A and B had mean OA values of $57.02 \pm 3.23$ and $124.30 \pm$ $7.26 \mathrm{kgm}^{-3}$ respectively. Regression model developed for predicting OA from TT and DOT had a coefficient of determination of 0.93 with a significant ANOVA result $(\mathrm{p}<0.05)$. Implications of the results obtained were discussed while conclusions and recommendations were made in line with the outcome of the study.

Keywords: Lignocellulosic materials; vegetable oil; preservative properties; test variables; non-
\end{abstract} pressure treatment.

\section{Resumo}

Absorção de óleo de sementes de nim (Azadirachta indica) por bambu fracionado (Bambusa vulgaris) em diferentes temperaturas e durações de tratamento. Este estudo foi realizado para avaliar a absorção de óleo de sementes de nim (Azadirachta indica A. Juss) por bambu fracionado (Bambusa vulgaris Schrad. Ex JC Wendl.) com amostras em duas temperaturas (TT) e diferentes durações do tratamento (DOT). Um modelo de regressão linear múltipla foi também desenvolvido para predizer a absorção de óleo (OA) de TT e DOT. Espécimes de bambu picado provenientes da mesma fonte com mesma dimensão foram secas em estufa a $103 \pm 2{ }^{\circ} \mathrm{C}$, condicionados a $11,76 \%$ de teor médio de umidade e tratados por imersão em óleo a uma temperatura ambiente de $25 \pm 2{ }^{\circ} \mathrm{C}$ por 24 horas (A), embebendo-se o outro em óleo quente a $60^{\circ} \mathrm{C}$ durante 4 horas (B). Os resultados obtidos mostraram que as amostras de teste para A e B tinham valores médios de 57,02 OA $\pm 3,23$ e 124,30 \pm 7,26 kg. $\mathrm{m}^{-}$ ${ }^{3}$, respectivamente. $\mathrm{O}$ modelo de regressão desenvolvido para predizer a OA de TT e DOT teve um coeficiente de determinação de 0,93, com um resultado da ANOVA significativo (p <0,05). Implicações dos resultados obtidos foram discutidos enquanto conclusões e recomendações foram feitas de acordo com o resultado do estudo.

Palavras-chave: Materiais lignocelulósicos; óleo vegetal; propriedades conservantes; variáveis de teste.

\section{INTRODUCTION}

Stems or culms of the different species of bamboo are lignocellulosic materials consisting of cellulose fibres embedded in a lignin matrix. These materials have been applied in the past and recently, for many applications, and presently there are still increasing research interests concerning them. One of such researches has been in the area of treating and preserving bamboo culms/stems with preservatives, owing to their poor inherent natural durability and easy susceptibility to agents of biodeterioration. The preservative treatment methods that are products of these researches are employed in applying 
preservatives in such ways as to, among other reasons, increase the culm's durability and service life (KUMAR et al., 1994; LIESE; KUMAR, 2003; LIESE, 2004).

In order to contribute to efforts aimed at treating lignocellulosic materials such as bamboo culms and others, using environmentally benign methods, it has been recommended that green plants which act as a reservoir for inexhaustible source of innocuous biocides, which are mammalian non-toxic and easily biodegradable than synthetic chemicals, be explored as a source of preservatives (VENMALAR; NAGAVENI, 2005; SINGH et al., 2006). Consequently, some studies based on the use of certain vegetable oil for treating this and other lignocellulosic materials against biodeterioration have been carried out and documented in literature.

Examples of such documented studies are the use of hemp seed oil (LEITHOFF; PEEK, 2001), palm oil (WAHAB et al., 2004), virgin coconut oil (MANALO; ACDA, 2009), linseed and castor oil (HONG, 2009), Neem Seed Oil (NSO) (ERAKHRUMEN, 2009; ERAKHRUMEN; OGUNSANWO, 2009; ERAKHRUMEN; OGUNSANWO, 2010; ERAKHRUMEN, 2011a), among others. Studies that were aimed at the use of NSO as preservatives were based on earlier reports that this oil possesses some anti-microbial properties (PARVEEN; ALAM, 1993; LOCKE, 1995; PURI, 1999) that may be exploited for this purpose even as most of the seeds produced by neem trees in many parts of Nigeria are presently underutilised owing to little or no socio-economic value attached to them (ERAKHRUMEN, 2010; ERAKHRUMEN, 2011b).

In addition, lack of adequate characterisation of some of the physical and chemical properties of this seed's oil in West Africa, Nigeria inclusive, might have been one of the reasons why this oil's antimicrobial properties, reported in literature, were not adequately recognised in this region. Owing to this, studies such as Erakhrumen (2010; 2011b) were carried out to further highlight the potentials of this oil, based on the reported properties in literature and the outcomes of these studies, as a preservative for lignocellulosic materials. As innovative as these and other similar studies were, one of the properties that have not been adequately reported is the quantity of oil absorbed by these lignocellulosics or oil absorption (OA) values, for instance, when oil-treatment is done at different or varied temperature regimes and Durations of Treatment (DOT).

Knowledge of the quantity of preservative absorbed by lignocellulosic materials as influenced by the treatment process(es) adopted is necessary since it may have effects on some other properties like penetration and distribution of preservatives in treated materials. Penetration and distribution have been observed to be some of the several treatment factors upon which the effectiveness of preservatives depend (ERAKHRUMEN, 2012). This study was therefore carried out in order to evaluate absorption values for neem (Azadirachta indica A. Juss) seed oil-treated split-bamboo (Bambusa vulgaris Schrad. ex J.C. Wendl.) at two different Treatment Temperature (TT) regimes and DOT. Predictive equation based on linear regression analyses was also developed for NSO absorption using the two variables (i.e. TT and DOT) as predictors.

\section{MATERIALS AND METHODS}

\section{Sourcing of bamboo stems}

The bamboo culms that were converted and experimented upon in this study were sourced from wild clumps at Isale-Togun Forest, Lanlate, Ibarapa, Oyo State, Nigeria (latitude $7^{\circ} 36^{\prime} \mathrm{N}$ and longitude $3^{\circ} 27^{\prime} \mathrm{E}$ ) in October, 2008. This area is located between the humid and sub-humid tropical climatic zones where mean annual rainfall ranges from 1117.10 to $1693.30 \mathrm{~mm}$. The harvested matured culms had no known age or history of management. It is on record that no quantitative parameters have been presently established to identify the different growth stages of a bamboo culm for adequate harvesting purposes (LONDOÑO et al., 2002).

In order to ensure minimal influence of age, lack of management, and other variables on the results from the research, only mature culms with mean circumferential length of $300 \mathrm{~mm}$ at the second node above ground were harvested and cross cut in such a way that only the basal culm portion of 3000 $\mathrm{mm}$ length were removed and placed in jute bags with nylon lined inner surface to avoid contamination from the soil. All the harvested culms in the bags were transported to and properly stored for 14 days in the wood workshop of the Department of Forest Resources Management, University of Ibadan, Ibadan, Nigeria, for conversion to the test specimens in compliance with the different test standards. 


\section{Sourcing of neem seeds}

The ripe neem seeds from which oil was mechanically extracted in this study were obtained from A. indica trees on the University of Ibadan campus located on the northern edge of the city of Ibadan, Nigeria (latitude $7^{\circ} 20^{\prime} \mathrm{N}$ and longitude $3^{\circ} 50^{\prime} \mathrm{E}$ ) of about 10.4 square kilometres. Ibadan lies at $200 \mathrm{~m}$ above sea level with a humid tropical climate $\left(27^{\circ} \mathrm{C}\right.$ average), a March - October rainy season $(1250 \mathrm{~mm})$ followed by a mild dry season. Collection of the seeds was done by placing clean nylon sheets around the stems of $A$. indica trees in such a way that it covered a substantial cross sectional area of the crown in order to directly collect the seeds as they fall from the branches.

The neem seeds were sourced in the months of June to early August of 2008. The seeds obtained were thoroughly washed using deionised water to remove dirt and other impurities and then air-dried in an open space with regular movement for aeration to ensure proper drying, a method also applied by Soetaredjo et al. (2008), to reduce the Moisture Content (MC) for proper crushing and to facilitate high oil volume recovery during mechanical extraction. The seeds were stored in a nylon lined jute bag and properly kept safely away from the reach of pest organisms and other animals that may contaminate the seeds, and subsequently daily air-dried as previously described with proper monitoring to prevent seed damage as a result of possible moisture fluctuations.

\section{Conversion of bamboo stems to experimental test samples}

The harvested bamboo stems were carefully sawn into longitudinal strips using circular and vertical breakdown sawing. Each strip was planed on both the inner and outer surface, using a planing machine, in order to obtain split-bamboo samples with mean culm thickness of $5 \pm 0.5 \mathrm{~mm}$ for the tests. The bamboo samples obtained is the part between the bamboo skin and the pith. Bamboo skin is the outermost part of cross-section of stem wall, where no vascular bundles are seen, while pith is the part of stem wall next to bamboo cavity, and this also does not contain vascular bundles (CHAND et al., 2006). The strips were then conditioned in the laboratory for 14 days.

After the conditioning period, the strips were converted to test specimens with dimension $20 \mathrm{~mm}$ (tangentially) x $60 \mathrm{~mm}$ (longitudinally) x $5 \mathrm{~mm}$ (radially). The test specimens were oven-dried and stabilised in the laboratory to $11.76 \%$ mean MC prior to oil-treating the samples and evaluation of their OA. This sample dimension was used for this experiment because it was impossible to obtain $B$. vulgaris with culm thickness of up to or more than $25 \mathrm{~mm}$ irrespective of age and position along the culm. It is also noteworthy that presently there is still no universally accepted standard for determining many of the physical and mechanical properties of bamboo (KUMAR et al., 1994; ERAKHRUMEN; OGUNSANWO, 2009).

\section{Moisture content determination for split-bamboo test samples}

Planed split-bamboo with mean culm thickness of $5 \pm 0.5 \mathrm{~mm}$ were converted to test samples for determining MC based on oven-drying method in accordance with ASTM D 4442-84, using equation 1.

$$
M C=[(W m-W o) / W o] \times 100
$$

Where: $M C=$ Moisture content;

$W m=$ Weight of specimens before oven-drying $(\mathrm{g})$

Wo $=$ Weight of specimens after oven-drying $(\mathrm{g})$.

\section{Extraction of neem seed oil}

There are several methods of extracting oil from the seeds of neem, such as mechanical pressing, supercritical fluid extraction, solvent extraction, among others (PURI, 1999). Mechanical extraction is the most widely used method to extract oil from neem seeds (FASINA; AJIBOLA, 1989; PURI, 1999), since this method is effective for seeds containing 30 to $70 \%$ oil (KETAREN, 1986). However, the oil obtained with this method may not be highly priced, since it is considered turbid and contains a significant amount of water as compared to those obtained by supercritical fluid extraction and solvent extraction (LIAUW et al., 2008).

In order to mechanically extract NSO, the seeds obtained from the wild were decorticated after air-drying them, separating the kernel from the shells and dirt, and then the kernels were subsequently air- 
dried again. Dried kernels were carefully pulverised into smaller particles using a seed grinder ensuring no significant loss of seeds' oil. Mechanical extraction of oil was performed by cold pressing the pulverised seeds using an oil expeller at a maximum pressure of $31 \mathrm{MPa}\left(31 \mathrm{Nmm}^{-2}\right.$ or $\left.4,500 \mathrm{psi}\right)$. Mechanical extraction was performed at this pressure until the oil stopped flowing. This oil extraction method is expected to allow for easy adoption by most of the target potential end-users.

These targeted end-users include but are not limited to the potential and existing cottage and small-scale forest industries interested in adding value to bamboo resource particularly in the rural areas of developing countries like Nigeria where the most investment is needed and the generation of employment is the most difficult (FOOD AND AGRICULTURE ORGANIZATION (FAO), 2001). These rural areas in the developing countries are mostly the locations where people living below poverty lines are concentrated (CANAGARAJAH, 1998). This oil extraction method have some advantages compared to the other methods, such as simple equipment and low investment, low operating cost, and that the oil does not undergo a solvent separation process, among others (FASINA; AJIBOLA, 1989).

\section{Treatment of split-bamboo test samples with the extracted oil}

The split-bamboo test samples to be treated with NSO were earlier stabilised in the laboratory to $11.76 \%$ MC. The stabilised samples for oil-treatment were subjected to two NSO-treatment regimes through (1) soaking a set of samples in oil at ambient room temperature of $25 \pm 2{ }^{\circ} \mathrm{C}$ for 24 hours and (2) soaking another set in hot oil at $60{ }^{\circ} \mathrm{C}$ for 4 hours, removed from the oil afterwards and allowed to cool in a dessicator at an ambient room temperature of $25 \pm 2{ }^{\circ} \mathrm{C}$. This method of NSO-treatments was also adopted in the experiments reported by Erakhrumen (2009); Erakhrumen and Ogunsanwo (2009); Erakhrumen and Ogunsanwo (2010); Erakhrumen (2011); Erakhrumen (2012). The maximum heat treatment temperature of $60^{\circ} \mathrm{C}$ was adopted in this research because strength and stiffness values used in practice for most lignocellulosic materials are valid for temperatures below $60^{\circ} \mathrm{C}$ (HOMAN; JORISSEN, 2004).

\section{Determining the quantity of neem seed oil absorbed by split-bamboo test samples}

Two sets of split-bamboo samples, each having ten specimens, with same dimensions, that were oven-dried and stabilised in the laboratory to $11.76 \%$ mean MC were treated with the extracted NSO in different containers using the two treatment methods i.e., soaking of samples in oil at ambient room temperature of $25 \pm 2{ }^{\circ} \mathrm{C}$ for 24 hours and soaking in hot oil at $60{ }^{\circ} \mathrm{C}$ for 4 hours and allowed to cool to the ambient room temperature in a desiccator. Soaking bamboo in preservative and allowing it to penetrate by capillary or wick action are the main non-pressure methods (ANONYMOUS, UNDATED). The values of OA were determined for split-bamboo samples based on mean weight gain over time, as also done by Silva Sobrinho Jr. et al. (2009). The OA values were calculated using equation 2.

$$
O A=W_{o} / V_{b}
$$

Where: $O A=$ Oil absorption $\left(\mathrm{kgm}^{-3}\right)$;

$W_{o}=$ weight of oil absorbed $(\mathrm{kg})$;

$V_{b}=$ volume of split-bamboo sample $\left(\mathrm{m}^{3}\right)$.

\section{Statistical analyses}

The OA values obtained for the ten test samples for each treatment type were subjected to basic descriptive statistical analyses such as mean, standard deviation and standard error of mean. Linear regression analysis was employed in developing predictive equation for OA using TT and DOT as predictors. The statistical package used for the analyses was Minitab $13^{\circledR}$ for Windows ${ }^{\circledR}$.

\section{RESULTS AND DISCUSSION}

The mean values for OA that were obtained using the two treatment regimes are represented in Figure 1 with the descriptive statistics i.e., standard deviation and standard error of mean on table 1 . Mean OA value for split-bamboo samples soaked in oil at ambient room temperature of $25 \pm 2{ }^{\circ} \mathrm{C}$ for 24 hours was $57.02 \mathrm{kgm}^{-3}$ while it was $124.30 \mathrm{kgm}^{-3}$ for split-bamboo samples soaked in hot oil at $60{ }^{\circ} \mathrm{C}$ for 4 hours. 


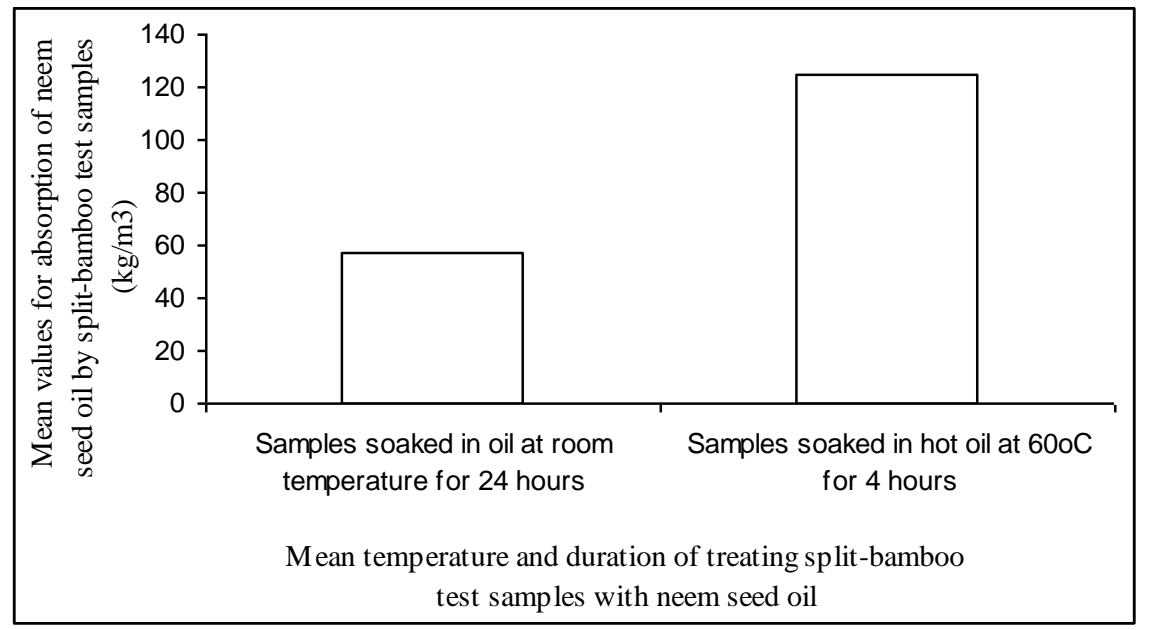

Figure 1. Graphical representation of mean oil absorption values for the two soaking methods Values are means for 10 test samples per each treatment.

Figura 1. Representação gráfica de valores médios de absorção de óleo para os dois métodos de embebição. Os valores são médias para 10 amostras de ensaio por cada tratamento

Table 1. Descriptive statistics for mean neem seed oil absorption by split-bamboo samples.

Tabela 1. Estatísticas descritivas para absorção média de óleo de sementes de nim por amostras de bambu picado.

\begin{tabular}{lcc}
\hline Treatment & Standard deviation & Standard error of mean \\
\hline Samples soaked in oil at ambient room temperature of & 3.23 & 1.03 \\
$25 \pm 2{ }^{\circ} \mathrm{C}$ for 24 hours & 7.26 & 1.11 \\
Samples soaked in hot oil at $60^{\circ} \mathrm{C}$ for 4 hours & \\
\hline
\end{tabular}

The implication of the OA values depicted in Figure 1 is that absorption of the oil by the splitbamboo test samples was higher in samples soaked in NSO at higher TT of $60{ }^{\circ} \mathrm{C}$ for 4 hours irrespective of the fact that the DOT was higher for split-bamboo samples treated with NSO at $25 \pm 2{ }^{\circ} \mathrm{C}$ for 24 hours. This trend appears to be in consonance with the observation of Hong (2009) in a study where the oil absorption percentage of materials made from two species of bamboo i.e., Moso bamboo (Phyllostachys edulis) and Ma bamboo (Sinocalamus latiflous) treated with three different kinds of oil, i.e., linseed oil, castor oil, and lard improved with increase in temperature, achieving higher oil absorption at higher oil temperature, similar to the observation by Erakhrumen (2012).

This study has been able to show that split-bamboo specimens were able to absorb this oil even at the prevalent ambient room temperature of $25 \pm 2{ }^{\circ} \mathrm{C}$, although, it is important to note that bamboo culms are observed to have low treatability partly because their tissue is quite resistant towards penetration of liquids due to their anatomical structure (LIESE, 1998). Whole bamboo culm is covered on the outside by a water-tight layer, the cuticula, and inwards by a suberin layer, which hinders side-ways penetration by simple treatments. Radial pathways, like the rays in timber do not exist, thus, uptake of a preservative is restricted mainly to the vessels at the culm ends (LIESE, 2007).

Nevertheless, studies have shown that bamboo is able to absorb different fluids of different densities over time, most likely due to capillary forces within the pore structure (SILVA SOBRINHO JR. et al., 2009). This ability to absorb different fluids of different densities over time will most likely lead to different absorption values regardless of the fact that data in this regard are presently scarce in literature. For instance, mean absorption of $70 \mathrm{kgm}^{-3}$ of creosote, a synthetic preservative, was recorded in some species of bamboo by Findlay (1985). Absorption and penetration of preservatives have been observed to be greater in split than in whole or round bamboo as the outer layer of bamboo is more or less impervious but the inner cuticle is permeable (ANON., UNDATED; LIESE, 2007). 
The implications of the result are, in the first instance that the absorption of this oil at the two treatment regimes are relatively high when compared to the few available data in literature and secondly, that the OA values were influenced by TT and DOT when split-bamboo was treated with this oil using the non-pressure methods in this research. This may not be unexpected as it has been noted that dipping airdry bamboo in hot preservatives was able to give good results (FINDLAY, 1985). It is noteworthy that treatability of bamboo is dependent on factors such as its anatomical structure, moisture content, treatment method, and type of preservative.

The two methods of treating split-bamboo samples in this study are non-pressure types where the soaked samples absorbed oil by allowing it to penetrate by capillary action. In bamboos, parenchyma and conducting cells are more frequent in the inner part of the wall whereas the peripheral zone is mostly fibres. Since there are no ray cells in bamboo for radial transportation of sap, preservatives for bamboo must have good diffusion properties, noting that the period of heating preservatives, if heat treatment is applied, also significantly influences its absorption (FINDLAY, 1985).

From the result obtained for OA values, it appeared that there is the likelihood that split-bamboo samples might absorb more or less oil if the TT and DOT are varied, thus, there was the need to develop a predictive equation, based on linear regression model, that will be helpful in estimating the quantity $\left(\mathrm{kgm}^{3}\right)$ of NSO to be absorbed at a combination of any TT and DOT using this type of non-pressure treatment method. The multivariate regression model of the type $\left(y=b_{0}+b_{1} x_{1}+b_{2} x_{2}\right)$ developed for predicting $\mathrm{OA}$ is depicted by equation 3 while the results of linear regression for the equation are tabulated on table 2 .

$$
\mathrm{OA}=10.7-0.050 \mathrm{DOT}+1.89 \mathrm{TT}
$$

Where: $\mathrm{OA}=$ Oil absorption $\left(\mathrm{kgm}^{-3}\right)$;

DOT = Duration of oil treating split-bamboo (hours);

$\mathrm{TT}=$ Treatment temperature $\left({ }^{\circ} \mathrm{C}\right)$.

Table 2. Results of linear regression for equation 3.

Tabela 2. Resultados de regressão linear para a equação 3.

\begin{tabular}{lcccc}
\hline Predictor & Coefficient & SE Coefficient & $\mathbf{R}^{\mathbf{2}}(\boldsymbol{\%})$ & $\mathbf{T}$ \\
\hline Constant & 10.74 & 24.07 & & 0.45 \\
DOT & -0.0495 & 0.6286 & 93.3 & -0.08 \\
TT & 1.8931 & 0.3579 & & 5.29 \\
\hline
\end{tabular}

$\overline{\mathrm{p}}<0.05$

The coefficient of determination $\left(R^{2}\right)$ in Table 2 obtained for the regression model (equation 3) showed that $93.3 \%$ represented the proportion of variation in the OA by split-bamboo test samples using both DOT and TT as predictors. This value obtained for $R^{2}$ was high enough for predictive purposes. Similarly, subjecting the regression equation to ANOVA, the result also showed that the predictive power of the equation was significant with $95 \%$ confidence. The same Table 2 also showed that the ratio of the corresponding value under coefficient, standard error of coefficients, and T-value reinforced the earlier discussed result by also showing that both DOT and TT significantly predicted OA in this study since the calculated values were greater than the pre-selected $\alpha$-level of 0.05 .

\section{CONCLUSION}

The following conclusions can be reached based on the outcome of this study:

- The oil absorption value was higher for split-bamboo test samples soaked in neem seed oil at $60{ }^{\circ} \mathrm{C}$ for 4 hours when compared to those soaked in the same oil at an ambient room temperature of $25 \pm$ $2 \mathrm{C}$ for 24 hours.

- The difference in oil absorption values for the two soaking methods appeared to be irrespective of the higher duration of treatment at the ambient room temperature of $25 \pm 2{ }^{\circ} \mathrm{C}$ for 24 hours.

- The likely implication of the results from the study is that variations in treatment temperature influenced oil absorption values, perhaps, more than duration of treatment. 
- Furthermore, the developed regression model also showed that oil absorption values could be predicted from different treatment temperature and durations of treatment with $95 \%$ confidence.

- Consequent on these results, it can be observed that in order to prevent ambiguities and discrepancies as it concerns oil absorption values for vegetable oil-treated lignocellulosic material, particularly bamboo, there will be the need to identify and state the treatment variables that may affect oil absorption values in the different treatment methods to be adopted.

- Finally, it is recommended that further studies be carried out regarding the use of vegetable oil and other plant extracts as preservatives for lignocellulosic materials.

\section{REFERENCES}

ANONYMOUS, UNDATED. Village Bamboo Preservation Unit. Available at: http://www.fao.org/ teca/es/content/village-bamboo-preservation-unit.

ASTM. Standard Test Methods for Direct Moisture Content Measurement of Wood and Wood-Base Materials. ASTM D4442-07. American Society for Testing and Materials, 2007.

CANAGARAJAH, S. Poverty and Welfare in Nigeria. Survey Report. Federal Office of Statistics and the National Planning Commission of the Federal Republic of Nigeria and the World Bank. American Writing Corporation, Washington, D.C., 22 pp, 1998.

CHAND, N.; JAIN, D.; NIGRAWAL, A. Investigations on Gradient A.C. Conductivity Characteristics of Bamboo (Dendrocalamus strictus). Bulletin of Material Science, v. 29, n. 2. p. 193 - 196, 2006.

ERAKHRUMEN, A. A. Evaluating the Efficacy of Neem (Azadirachta indica A. Juss) Seed Oil Treatment for Bambusa vulgaris Schrad. against Pycnoporus sanguineus (L. ex Fr.) Murr. using Static Bending Strength Properties. Forest Pathology, 2011a. DOI: 10.1111/j.1439-0329.2011.00741.x

ERAKHRUMEN, A. A. Influence of Treatment Temperature Regimes and Durations on the Absorption of Crude Neem (Azadirachta indica A. JUSS) Seed Oil by Split-Bamboo (Bambusa vulgaris SCHRAD.). Paper accepted for oral presentation at, and publication in the proceedings of, the $9^{\text {th }}$ World Bamboo Congress with the Theme "Bamboo Biosciences, Bioengineering and Agroforestry Potentials" scheduled for Antwerp, Belgium, from the $10^{\text {th }}$ to $15^{\text {th }}$ of April, 2012.

ERAKHRUMEN, A. A. Potentials of Neem (Azadirachta indica A. JUSS) Seed Oil as a Preservative for Bamboo (Bambusa vulgaris SCHRAD. EX J.C. WENDL.) against Basidiomycetes. An unpublished Thesis for a Ph.D. Degree of the University of Ibadan, Ibadan, Nigeria, xviii + 172 pp, 2010.

ERAKHRUMEN, A. A. Selected Physical and Chemical Properties of Mechanically Extracted Neem Seed Oil Sourced as a Preservative for Ligno-Cellulose in South-Western Nigeria. Forestry Studies in China, v. 13, n. 4, p. 263 - 269, 2011 b.

ERAKHRUMEN, A. A. Tensile Strength Properties of Wild Grown Bambusa vulgaris Treated with Neem Seed Oil in Southwest Nigeria. Journal of Bamboo and Rattan, v. 8, n. 1/2, p. 95 - 102, 2009.

ERAKHRUMEN, A. A.; OGUNSANWO, O. Y. Influence of Neem Seed Oil-Treatment on Static Bending Strength Properties of Wild Grown Split-Bamboo (Bambusa vulgaris Schrad.) in South-West Nigeria. Silva Lusitana, v. 18, n. 2, p. 167 - 177, 2010.

ERAKHRUMEN, A. A.; OGUNSANWO, O. Y. Water Absorption, Anti-Swell Efficiency, and Dimensional Stability Properties of Neem Seed Oil-Treated Wild Grown Bambusa vulgaris Schrad ex J.C. Wendl. in Southwest Nigeria. BioResources, v. 4, n. 4, p. 1417 - 1429, 2009.

FAO. Socio-Economic Aspects of Bioenergy: A Focus on Employment by Remedio, E. M. of the Food and Agriculture Organization of the United Nations (FAO), Rome, 2001.

FASINA, O. O.; AJIBOLA, O. O. Mechanical Extraction of Oil from Conophor nut (Tetracarpadium conophorum). Journal of Agric. Engng. Res., v. 44, p. 275 - 287, 1989. 
FINDLAY, W. F. K. Preservation of Timber in the Tropics. Published by Martinus Nijhoff / Dr. W. Junk Publishers, Dordrecht, The Netherlands. ISBN 90-247-3112-7, 1985.

HOMAN, W. J.; JORISSEN, A. J. M. 2004. Wood Modification Developments. HERON, v. 49, n. 4, p. 361 - 386.

HONG, K-J. Studies on Dimensional Stability and Anti-Mildewing Ability of Oil-Treated Bamboo. A Dissertation/Thesis submitted to Department of Forestry, College of Agriculture and Natural Resources, National Chung Hsing University, 2009. Abstract available at: http://ir.lib.nchu.edu.tw/handle/ $309270000 / 27685$.

KETAREN, S. Pengantar Teknologi Minyak dan Lemak Pangan, Jakarta: UI-Press. p. 201, 1986.

KUMAR, S.; SHUKLA, K. S.; DEV, T.; DOBRIYAL, P. B. Bamboo Preservation Techniques: A Review. Jointly published by International Network for Bamboo and Rattan (INBAR) and Indian Council of Forestry Research Education (ICFRE). 1994. Also available at: http://www.inbar.int/publication/ txt/INBAR_Technical_Report_No03.htm.

LEITHOFF, H.; PEEK, R. D. Heat Treatment of Bamboo. IRG/WP 01-40216. Prepared for the $32^{\text {nd }}$ Annual Meeting of the International Research Group on Wood Preservation Nara, Japan from $20^{\text {th }}$ to $25^{\text {th }}$ of May, 2001, $11 \mathrm{p}$.

LIAUW, M. Y.; NATAN, F. A.; WIDIYANTI, P.; IKASARI, D.; INDRASWATI, N.; SOETAREDJO, F. E. Extraction of Neem Oil (Azadirachta indica A. Juss) using N-hexane and Ethanol: Studies of Oil quality, Kinetic and Thermodynamic. ARPN Journal of Engineering and Applied Sciences, v. 3, n. 3, p. $49-54,2008$.

LIESE, W. Preservation of Bamboo Structures. Ghana Journal of Forestry, v. 15 \& 16, p. 40 - 48, 2004. Protection of Bamboo Structures. Paper presented at XXIII Sympozjum Rogów, Polska Akademia Nauk, Komitet Technologii Drewna held from $5^{\text {th }}$ to $7^{\text {th }}$ of September, 2007, 7 pp, 2007.

The Anatomy of Bamboo Culms. International Network for Bamboo and Rattan (INBAR)

Technical Report Number 18: 204 pp, 1998.

LIESE, W.; KUMAR, S. Bamboo Preservation Compendium. International Network for Bamboo and Rattan (INBAR) Technical Report Number 22: 231pp, 2003.

LOCKE, J. C. Fungi. In: The Neem Tree, Source of Unique Natural Products for Integrated Pest Management, Medicine, Industry and Other Purposes. Edited by Schmutterer, H. VCH, Weinheim, Germany, p. 118 - 125, 1995.

LONDOÑO, X.; CAMAYO, G. C.; RIAÑO, N. M.; LÓPEZ, Y. Characterization of the Anatomy of Guadua angustifolia (Poaceae: Bambusoideae) culms. Bamboo Science and Culture, v. 16, n. 1, p. 18 31, 2002.

MANALO, R. D.; ACDA, M. N. Effects of Hot Oil Treatment on Physical and Mechanical Properties of Three Species of Philippine Bamboo. Journal of Tropical Forest Science, v. 21, n. 1, p. 19 - 24, 2009.

PARVEEN, G.; ALAM, M. M. Bioactivity against Plant Pathogens. In: Neem Research and Development. Edited by Randhawa, N. S.; Parmar, B. S.; Society of Pesticide Science, New Delhi, India, p. $144-153,1993$.

PURI, H. S. Neem: The Divine Tree, Azadirachta indica. Harwood Academic Publications, Amsterdam. ISBN 90-5702-348-2, 1999.

SILVA SOBRINHO JR., A.; ARAGÃO JR., J. L. de; TORRES, S. M.; BARROS, S. de; ORTIZ, S. R.; BARBOSA, N. P. Bamboo pH and Absorption in Different Liquids. Proceedings of the $11^{\text {th }}$ International Conference on Non-conventional Materials and Technologies (NOCMAT 2009) $6^{\text {th }}$ to $9^{\text {th }}$ of September 2009, Bath, UK. 2009. Also available at: http://opus.bath.ac.uk/16170/1/papers/Paper\% 20155.pdf. 
SINGH, T.; CHITTENDEN, C.; VESENTINI, D. In vitro Antifungal Activity of Chilli against Wood Degrading Fungi. IRG/WP 06-10572. A Paper prepared for the $37^{\text {th }}$ Annual Meeting of the International Research Group on Wood Protection held in Troms $\varnothing$, Norway, 2006, 11 p. 2006.

SOETAREDJO, F. E.; BUDIJANTO, G. M.; PRASETYO, R. I.; INDRASWATI, N. Effects of PreTreatment Condition on the Yield and Quality of Neem Oil obtained by Mechanical Pressing. ARPN Journal of Engineering and Applied Sciences, v. 3, n. 5, p. 45 - 49, 2008.

VENMALAR, D.; NAGAVENI, H. C. Evaluation of Copperised Cashew Nut Shell Liquid and Neem Oil as Wood Preservatives. IRG/WP 05-30368. Prepared for the $36^{\text {th }}$ Annual Meeting of the International Research Group on Wood Protection held in Bangalore, India, 2005, 20 p.

WAHAB, R.; SAMSI, H. W.; SUDIN, M.; MOKTAR, J. Strength and Durability of Bamboo Treated through an Oil-Curing Process. Journal of Biological Sciences, v. 4, n. 5, p. 658 - 663, 2004. 
